ISSN:2528-9527

E-ISSN: 2528-9535

Yıl Year: 11

Cilt Volume: 18

Sayı Issue: Yönetim ve Organizasyon Özel Sayısı

Temmuz July 2021

Uluslararası Toplum Araştırmaları Dergisi International Journal of Society Researches

Makalenin Geliş Tarihi Received Date: 12/03/2021

Makalenin Kabul Tarihi Accepted Date: 28/04/2021

\title{
Personel Güçlendirmenin İşletmeler Açısından Önemi
}

\author{
DOI: $10.26466 /$ opus. 895900 \\ Seçil Ulufer Kansoy * \\ * Dr. Öğr. Üyesi, İstanbul Aydın Üniversitesi., İstanbul/Türkiye \\ E-Posta: secilulufer@aydin.edu.tr ORCID: 0000-0002-5522-324X
}

Öz

Sanayileşme döneminde üretim odakl çalışan işletmeler için personelden çok üretim miktarının önemi daha fazla olmuştur. O dönemlerde işgörenlerden sadece söylenileni yapmalar ve üretmeleri istenmiş, herhangi bir söz hakkı tanınmamıştır. Modern yönetim anlayışına sahip işletmeler çalışanlarına yetki ve sorumluluklar vererek üretim odaklılıktan çıkarak insan odakl üretimi esas almışlardır. Bir işletmede, yapılan işin niteliğine göre bir iş hakkında en iyi bilgi ve beceriyi o işi yapan çalışanlar bilebilir. Bu noktada personel ne kadar güçlendirilirse işletme de o derece güçlü olacaktır. Personel güçlendirme kavramı yardımlaşma, ekip çalışması, işin paylaşımı gibi çalışmalarla personelleri geliştirme, yetiştirme ve işi yapan personellerin karar verme yetkilerinin arttırılması sürecini kapsamaktadır. Personel güçlendirme, belirli bir çalışan grubunu değil, işletmelerde görev yapan tüm personelleri içermektedir. Bu çalışmada personel güçlendirmenin işletmeler açısından önemi üzerinde durulmuştur. Yapılan literatür incelemeleri doğrultusunda nitel olarak gerçekleştirilen çalışmanın sonuçlarına göre; personel güçlendirmenin üretim maliyetlerinde ve işten ayrılmalarda düşüş sağladığı, kurumsal imajda vb. iyileşmelerin yan sıra müşteri memnuniyetinde ve işgören bağlılığında artışa neden olduğu anlaşılmaktadır.

Anahtar Kelimeler: Personel Güçlendirme, Yönetim, Işsletme. 
ISSN:2528-9527

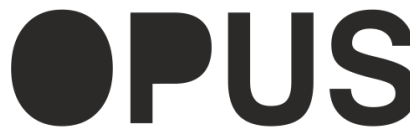

Uluslararası Toplum Araştırmaları Dergisi International Journal of Society Researches
E-ISSN: 2528-9535

Yıl Year. 11

Cilt Volume: 18

Sayı Issue: Yönetim ve Organizasyon Özel Sayısı

Temmuz July 2021

Makalenin Geliș Tarihi Received Date: 12/03/2021 Makalenin Kabul Tarihi Accepted Date: 28/04/2021

\title{
The Importance of Personnel Empowerment for Businesses
}

\begin{abstract}
During the industrialization period, production importance was much more valuable than workers for the companies that work production oriented. During those times, employees were just expected to do what was assigned and produce along with not having been given any right of self expression. Abondoning the production oriented understanding and giving authority an responsibility to their workers, the companies with modern management understanding gave importance to the approach of worker oriented production. In a business, the employees who perform a specific duty have the best skills and know the best knowledge about it based on the quality of the work done. At this very point, the more the employees are empowered, the more powerful the business will be to that extent. The concept of personnel empowerment includes training and developing them utilizing from cooperation, team work and division of labor as well as the processes like expanding employees' the authority of decisionmaking. Personnel empowerment doesn't consist of only a specific group work employees but all the employees that work in the businesses. In this study, the importance of personnel empowerment in terms of businesses is emphasized. Following the literature review and according to the qualitative research it is shown while personnel empowerment leads to decrease in production costs and turnovers, it leads to an increase in customer/client satisfaction, employee commitment and corporate image.
\end{abstract}

Keywords: Personnel empowerment, Organization, Business. 


\section{Giriş}

İşletmeler mal ve hizmet üretimlerini gerçekleştirmek için istihdam ettikleri personelin yeterliliklerinin ve bilgilerinin yüksek nitelikte olmasını isterler. Bu amaçla çeşitli yol ve yöntemlerle personel seçmeye çalışırlar. Sonuç olarak kendilerine göre uygun personeli istihdam ederler. Ancak zaman içerisinde gelişen teknolojiler, ortaya çıkan rakipler, mal ve hizmet üretimlerinde meydana gelen çeşitlilik, üretim yöntem ve tekniklerindeki yenilikler vb. sonucunda personelin yeterlilikleri kâfi gelmeyebilmektedir. Bu noktada personel güçlendirme konusu gündeme gelmektedir. Örneğin 1980'li yıllarda bankalarda daktilolar kullanılmaktayken bilgisayarların yaygınlaşması karşısında banka personelinin eğitilmesi ihtiyacı duyulmuştur. Endüstri 4.0 ekosistemi ile yapay zekâ, bulut bilişim, büyük veri ve sibernetik fiziksel sistemler gibi bilgi iletişim teknolojileri alanında yaşanan gelişmeler ve dijital dönüşüm (Çark, 2020) ile birlikte işletmelerin nitelikli ve kalifiye personele olan ihtiyaçları daha da artmıştır (Çark, 2021).

Personel güçlendirme (empowerment) kısaca bir işgörenin işini etkin bir şekilde yapma yeteneğinin artırılarak, şimdiki ve gelecekteki performanslarının iyileştirilmesi yönündeki girişimler ya da eylemler olarak tanımlanabilir (Bingöl, 2014). Küreselleşmeyle artan rekabet şartlarında başarılı olunabilmesi, çeşitli bilgilerle, becerilerle ve yeteneklerle donanmış, yüksek motivasyona sahip, kendi amaçlarıyla, işletme amaçlarını uyumlaştırmış işgücüne sahip olmak gerekir (Özçelik, 2015). Günümüzde tüm işletmeler personel güçlendirmenin gerektiğini tartışmasız kabul etmektedirler. Tartışma daha çok hangi görevler için güçlendirme yapılacağı ve bu güçlendirmenin yapılmasında hangi yöntemlerin kullanılması üzerine yapılmaktadır (Schuler, 1995). Personel güçlendirme işletmelerde performansın artırılmasında önemli bir rol üstlenmektedir. Dolayısıyla işletmeler işgörenlerini ihtiyaç duyulan alanlarda zaman zaman geliştirme programlarına alarak küresel rekabetteki konumlarını yükseltmeye çalışmalıdırlar. Bu aynı zamanda personelin motivasyonunu da artırarak verimliliklerini yükseltecektir. Bu çalışmada personel güçlendirmenin işletmeler açısından önemi üzerinde durulmuştur. 


\section{Personel Güçlendirme Kavramı}

İşgörenlerin güçlendirilmesi rekabet avantajı sağlayabilmek için önemlidir. Bu nedenle, işgörenlerin güçlendirilmesi için yapılan uygulamaların yaratıcılığın ve yenilikçiliğin ön şartı olduğu kabul edilmektedir. Bu bağlamda personel güçlendirme kavramı, çağdaş yönetim uygulamaları içerisinde en çok ilgi gören kavramlardan biri olmuştur (Çavuş, 2012) .

Personel güçlendirme, süratle değişen pazar koşullarının, gelişen ve değişen işgören nitelik ve beklentilerinin, farklılaşarak sürekli bir şekilde artan müşterilerin beklenti gereksinimlerine hızlıca ve etkili bir şekilde cevap verme ihtiyacının doğurduğu modern yönetim kavramlarından birisidir (Doğan, 2006).

Personel güçlendirme, personel yetiştirme kavramına yakın bir kavram olmakla birlikte aslında birbirlerinden farklı kavramlardır. Personel yetiştirme, bir meslek ya da hizmette görev alacak bireyleri nitelikli elemanlar haline getirmeyi ifade ederken, personel güçlendirme ise böyle yetiştirilmiş ve bir meslekte ya da hizmette çalışan elemanların eğitilmesi ya da bilgi, beceri yeteneklerinin yükseltilmesini ifade etmektedir (Tanyeli, 1970). Personel güçlendirme, bireylerde bulunan bilgi, beceri ve yeteneklerin hali hazırdaki işini yapması için yeterli olsa da gerek bireylerin daha verimli çalışmaları gerekse de değişik birimlerde istihdamları için bilgi, beceri ve yeteneklerin geliştirilmesidir (Özçelik, 2015).

Özgen ve Türk (1997)'e göre personel güçlendirme, işgörenlerin iş birliği halinde birbirleri ile yardımlaşarak, karşılıklı güven çerçevesi içerisinde kendi iş alanları üzerinde karar vermelerine imkân tanıyan bir anlayıştır.

Personel güçlendirme, işletmelerdeki karar alma süreçlerinin merkezden uzaklaştırılmasıdır. Bu şekilde üst yönetim personele otonomi ve inisiyatif hakkı sağlamış olur. Bu anlamda personel güçlendirmeyle işletme problemlerinin bir an önce çözümlenmesi sağlanır (Doğan, 2003a).

Personel güçlendirme kavramı, motivasyon kavramı ile de yakından ilgili olmakla birlikte bazı farklılıklar göstermektedir. Motivasyon bir ya da birden çok kişiyi, belirli bir amaca doğru harekete geçirmek için yap1lan çabalar toplamı şeklinde ifade edilebilir. Tanımdan da anlaşılabileceği gibi, motivasyonun temelinde işgörenlerin performanslarını artırmak için uygun şartların ve ortamların yaratılması söz konusudur. İşgö- 
renlerin nasıl kontrol edilecekleri ve yönlendirilecekleri önem taşır. Güçlendirme kavramında kontrol iş görenlerdedir ve işletmenin asıl amacı işgörenlerin kendilerini yetiştirmeleri ve sonucunda işlerinde başarılı olabilmeleri için gerekli kararları almalarıdır. İşgörenleri motive etmek için çeşitli özendirme araçlarına ihtiyaç duyulur. Gelir, terfi, güvenlik, statü kazanma, daha cazip iş, kararlara katılma, kişisel güç ve otorite kazanma, adil olma ve devamlı disiplin gibi özendirme araçları insanların motive olmalarını sağlayabilmektedir. Personel güçlendirmede artırılmış özgüven, ilerleme arzusu, kendini geliştirme, değişime açık olabilme, risk alabilme, bağımsız çalışabilme, kendinin farkında olabilme, kendini ifade edebilme gibi kişisel beceriler ön plana çıkmaktadır. Sonuçta, motivasyonda zaaflardan yararlanma öne çıkmaktayken, güçlendirmedeyse üstün yetenekler öne çıkmaktadır. Motivasyon, kişilerin belli amaçlar etrafında harekete geçirilmesine dönük olup dürtülerin, güdülerin ve ihtiyaçların bir sonucu olarak ortaya çıkmaktadır (Çuhadar, 2005).

Personel güçlendirme, işgörenlerin, motivasyonlarının, bilgilerine ve yeteneklerine olan güvenlerinin arttığı, takdir haklarını kullanarak harekete geçmek istedikleri, olayları kontrol edebilecekleri inançlarının arttığ1 ve işletmenin amaçlarıyla uyumlu ve anlamlı buldukları işler yapmalarını sağlayan uygulamalar ve koşullardır (Koçel, 2005).

Personel güçlendirme "katılımlı yönetim", "sorumluluğun dağıtılmas1" ya da "herhangi bir yönetim tanımı"nın ötesinde bir kavram olup, "bireyleri daha güçlü kılmaktır". Fakat bu güçlü kılma maddi anlamda değildir. Sözü edilen güçlü kılma, onları geliştirme, daha bilgili hale getirme, kendilerine güvenmelerini sağlama ve diğerleriyle faydalı ve yapıcı ilişkiler kurma yeteneklerini güçlendirme anlamındadır (Doğan ve Demiral, 2007).

\section{Tarihsel Gelişim}

Küreselleşmeyle beraber yoğunlaşan rekabet sebebiyle işletmelerde merkezden karar almanın etkinliği azalmıştır. Günümüzdeki işletmeler, sorunlara hızlı ve doğru çözüm üretebilen, inisiyatif alabilen ve verdiği kararların sonuçlarının neden olabileceği sorumluluğunu taşıyabilen çalışanlara gerek duymaktadırlar. Bu sebeple daha hızlı, esnek, etkili ve 
cesur kararların alınabilmesi için işin içerisinde doğrudan bulunanların güçlendirilmesi bir zorunluluk haline gelmiştir (Barutçugil, 2004).

1920'li yıllarda Taylor'un öne sürmüş olduğu ve çalışanları birer makina gibi algılayan yönetimsel yaklaşım, işletmelerin verimlilikleri üzerinde olumlu sonuçlara neden olduysa da işe devamsızlık ve işgücü devri gibi çalışanların performanslarını olumsuz yönde etkileyen bazı durumlar oluşturmasından dolayı ağır eleştirilerin hedefi olmuştur (Eren, 1998).

1950'lerde insanın merkezde olduğu yaklaşım benimsenmiş ve insana verilen değer artmıştır. Elton Mayo'nun liderliğinde açılan ve Taylorist görüşü eleştiren beşerî ilişkiler okulu, çalışanların kendi kendilerine motive olabileceklerini ve katı bir denetim olmaksızın da iyi işler çıkarabileceklerine vurgu yapmıştır (Wilkinson, 1998).

Müşterilerin merkezde olduğu toplam kalite yönetimi felsefesi ile beraber, işletmelerin hiyerarşik yapılarında değişime gidilmiştir. Böylece müşterilerin taleplerinde ve beklentilerindeki değişimlere uyabilen, esnek, uzmanlaşmaya sahip, merkezi yapıdan uzak işletmeler türemiştir (Güven, 2001).

Personel güçlendirmenin günümüzdeki anlamından 1980'li yılların sonunda bahsedilmeye başlanmıştır. Peters ve Schonbergerin büyük bir ısrarla savundukları personel güçlendirme kavramıla ilgili yayınlar yapılmaya başlanmıştır. Bu kavramın ilk kullanıcıları arasında sırasıyla Harrison ve Kanter (1983), Bennis ve Naus (1985), Burke ve Neilsen (1986) yer almaktadır. Kavram ilk kullanıldığı zaman tam anlamıla genel kabul görmüş bir tanımı yapılmamıştır. Kavram Block'un çalışmaları ile asıl ününü kazanmış ve yeni yönetim şekli olarak kabul edilmiştir (Doğan, 2003a).

\section{Personel Güçlendirmenin Çeşitleri}

Literatürde personel güçlendirme ile ilgili iki yaklaşım söz konusudur. Bunlar yapısal ve psikolojik personel güçlendirme yaklaşımlarıdır. Bu yaklaşımlara aşağıda kısaca değinilmiştir.

Yapısal personel güçlendirme: Yapısal güçlendirme yaklaşımı, Kanter tarafından 1993'de geliştirilmiştir. Kanter bu yaklaşımıyla işgörenlerin 
davranışlarını etkileyen koşulları araştırmış ve yapısal güçlendirme ile ilgili dört yapıyı ortaya koymuştur. Bunlar; işgörenlerin kendilerini geliştirebilmeleri için mesleklerinin sınırlarının dışındaki faaliyetlere katılabilmeleri, işletmeleriyle ilgili tüm bilgilere ulaşabilmeleri, karar verme inisiyatifine sahip olabilmeleri, işgörenlerin istediklerinde kaynaklara ulaşabilmeleri şeklinde sıralanabilir (Allanazarov, 2008).

Psikolojik personel güçlendirme: Psikolojik personel güçlendirme yaklaşımında, yapılanların işgörenlerce nasıl algılandığına odaklanılmaktadır. Psikolojik güçlendirme algıları ile (anlam, yetkinlik, özerklik, etki) performans arasında pozitif bir ilişki olduğu ifade edilmektedir (Spreitzer, 1995). Psikolojik güçlendirme, güçsüzlüğe neden olan şartların tespit edilmesiyle, resmi kurumsal uygulamaların ve yeterlilik bilgisi sağlayan gayri resmî tekniklerin ortadan kaldırılmasıyla işgörenlerin özyeterlilik duygusunu artırma sürecidir (Humborstad and Perry, 2011). Özyeterlilik algisının güçlendirilmesi, bireysel güçsüzlüklere neden olan örgütsel faktörlerin indirgenmesiyle mümkündür (Arslantaş, 2007).

\section{Personel Güçlendirmenin Boyutları}

Personel güçlendirmenin boyutları, anlam, yetkinlik, seçim ve etki olarak dört boyuttan oluşmaktadır. Bunlardan aşağıda kısaca bahsedilmiştir.

Anlam: Anlam, bireylerin kendi standartlarıyla görev amaçlarının değeri arasındaki ilişkinin bir ifadesidir. Anlamlılık derecesinin düşüklüğü, bireylerin önemli olayların karşısında ilgisizliğiyle sonuçlanır. Anlamlılık derecesinin yüksek olması durumundaysa katılım, bağlılık ve enerjinin yoğunlaşması söz konusudur (Ceylan vd., 2005).

Yetkinlik: Yetkinlik bir işgörenin üzerine düşen görev ve faaliyetleri gerçekleştirebilme derecesidir. Yetkinlik boyutu Bandura (1989) tarafından özyeterlilik veya ustalık olarak ifade edilmiştir. Bandura özyeterlilikleri düşük olan işgörenlerin, işleriyle ilgili becerilerinin gerektirdiği şartlardan kaçındıklarını gözlemiştir. Özyeterliliklerinin yüksek olması halindeyse işgörenler gereken davranışları, yüksek çaba ve sorunlarla karşılaştı̆̆ında bile kararlılıkla göstermektedirler. 
Seçim: Personel güçlendirmenin seçim boyutu işgörenlerin şahsi eylemlerinin denetimine ilişkin sorumluluklarını içermektedir. Seçim algısı, esneklik, yaratıcılık, inisiyatif, zorlukların üstesinden gelme gücü ve öz düzenleme sağlar. Tersi durumda bireyler, kendilerini olayların kontrolü altında hissediyorlarsa, bu durumda gerilimler, olumsuz duyguları ve benlik saygılarında düşüşs söz konusu olur (Bolat, 2008).

Etki: Personel güçlendirmenin etki boyutu, davranışların, görevlere dair amaçlara ulaşılmasında "bir fark yaratma" durumunun ifadesidir. İşgörenin, işin stratejisi, yönetimi ya da sonuçlarında tesir yetkisine sahip olmasıdır. Etki işgörenlerin yaptıkları işlerin sonuçları üzerindeki kontrol duygularına işaret eder (Thomas and Velthouse, 1990). İşgörenlerin işleriyle ilgili yönetsel, stratejik ve işlemsel çıktıları etkileyebilme derecesi ve bunlara ilişkin algılamalardır (Gümüştekin ve Emet, 2007).

Yukarıda anılan boyutlar bir araya geldiğinde psikolojik güçlendirmeyle ilgili bütüncül bir kavram oluşur. Diğer taraftan herhangi bir boyutun eksik kalması, hissedilen güçlendirmeyi tümüyle ortadan kaldırmasa da derecesini azaltmaktadır. Bu sebeple bu boyutlar birlikte psikolojik güçlendirmeyi anlayabilmek için gereken "tam ve yeterli bilişsel set" olarak nitelendirilir (Çöl, 2004).

\section{Personel Güçlendirmenin Unsurları}

Bir işletmede personel güçlendirme anlayışının benimsenebilmesinde örgüt kültüründeki bazı unsurların varlığı önemlidir. Çalışana sorumluluk, kararlara katılma yetkisi, yenilik, bilgiye erişebilirlik ve bilginin paylaşılması, ortak hedeflerde hareket edebilme, çalışanlara güven verme, açık bir iletişim ortamı, eğitim ve geliştirme, ekip çalışması, çalışma ortamlarında iyileşme ve esneklik, çalışanları takdir etme, yeterlilik ve yetenekleri geliştirme ve performans ile ilgili geri-bildirim yapılması gibi unsurlar kültürün oluşması ve devamlılığının sağlanması açısından önemlidir (Doğan, 2003b). 


\section{Personel Güçlendirme Süreci}

Personel güçlendirme sürecinin başarılı olabilmesi için işletmelerde paylaşılan bir vizyon oluşturulmalı, personele eğitim olanağ1 verilmeli, güçlendirmeyi engelleyecek bireysel, yönetsel ve örgütsel faktörler ortadan kaldırılmalı, üstler ve astlar birbirlerine açık ve net olmalı, güçlendirilecek olan personel desteklenmeli, sürecin değerlendirilmesi yapılmalı ve aksayan yönler düşünülerek gereken önlemler alınmalıdır (Baltaş, Değişimin İçinden Geleceğe Doğru Ekip Çalışması ve Liderlik, 2001).

Başarılı bir personel güçlendirme uygulaması için gereken faktörler şu şekilde sıralanabilir (Russ, 1995):

- Personel güçlendirme, bir teknik olarak değil, bir felsefe olarak kabul edilmeli,

- Değerlendirmede açık ve gerçekçi olunmalı,

- Anlayış, bilgi ve yetenek ön planda olmalı,

- Beklentiler gerçekçi olmalı,

- Başarısızlıklar öğrenme için bir fırsat olmalı,

- Personel güçlendirmede sabredilmeli.

Personel güçlendirme basit bir şekilde ele alınmamalı, dinamik bir çevrede ve süregiden bir süreç olarak düşünülmelidir. Örgütsel ve yerel iş çevresi personel güçlendirmenin ilk ve en önemli aşaması olup, bireysel yönünü oluşturan işgörenlerin, destek, fırsat, güven ve sadakat gibi algılarını ve tutumlarını etkiler. İşgörenlerin sahip oldukları bu algılar ve tutumlar aracılığıyla örgütsel ve yerel iş çevresinden gelen etmenler psikolojik personel güçlendirmenin oluşumunda önemli bir görev üstlenmektedir. Psikolojik personel güçlendirmenin dört temel unsuru olan etki, anlam, yetkinlik ve seçimin güçlendirilmiş davranışlara dönüşmesi ile süreç tamamlanır (Robbins, Crino, and Fredendal, 2002). Personel güçlendirme sürecinde yapılması gereken bazı faaliyetler tablo 1'de verilmiştir. 
Tablo 1. Personel Güçlendirmede Yapılması Gereken Bazı Faaliyetler

\begin{tabular}{|c|c|c|c|c|}
\hline \multirow[b]{2}{*}{ Faaliyetler } & \multicolumn{4}{|c|}{ Personel Güçlendirme Ölçütleri } \\
\hline & Etki & Yetkinlik & Anlam & Seçim \\
\hline Yetki Devri & & & & $\mathrm{X}$ \\
\hline Katılımcı Karar Verme & & & & $x$ \\
\hline Kendi Kendine Yönetmeyi Cesaretlendirme & & $x$ & & $\mathrm{x}$ \\
\hline İş Zenginleştirme & $\mathrm{x}$ & & $x$ & $x$ \\
\hline Kendi Kendini Yönetebilen Takımlar Oluşturma & $x$ & & $x$ & $x$ \\
\hline Doğal Bir Geri Besleme Gerektiren Görevler & $x$ & & & \\
\hline \multicolumn{5}{|l|}{ Oluşturma } \\
\hline Aşağıdan Yukarıya Performans Değerleme & & & $x$ & \\
\hline Resmiyetin Azaltılması & & & & $\mathrm{X}$ \\
\hline Çalışanı Destekleyici Bir Kültür Yaratılması & $x$ & & $x$ & $\mathrm{x}$ \\
\hline Amaç Geliştirmeyi Cesaretlendirme & $x$ & & & \\
\hline Çalışanları Eğitmek ve Yetiştirmek & & $x$ & & \\
\hline
\end{tabular}

Kaynak: (Doğan, 2003b)

Güçlendirmenin yönetsel uygulamalarla gerçekleşebileceği düşünüldügünde güçlendirme konusunda üst yönetime bazı görev ve sorumluluklar düşmektedir. Bunlar aşağıdaki gibi sıralanabilir (Çöl, 2004):

- Güçlendirmeye yönelik örgütsel bir kültür oluşturmak,

- Örgüt içinde paylaşılan bir vizyon yaratmak,

- Örgüt içinde güven ve bağlllık yaratmak ve yabancılaşmayı azaltmak,

- Bilgi paylaşımını mümkün kılmak (örgütün amaçları, stratejileri, vizyonu ve bireysel ve örgütsel performans hakkındaki bilgiler),

- İşleri planlama, karar verme ve kontrol boyutunda zenginleştirmek,

- Çalışanları işlerini yaparken izledikleri yollar ve verdikleri kararlar konusunda cesaretlendirerek bir öğrenme ortamı oluşturmak (hataları öğrenme fırsatı olarak görmek),

- Örgüt içinde katılımı ve yetki devrini arttırmak,

- Örgüt içinde çift yönlü bir iletişim sistemi kurmak ve uygulanmasını sağlamak,

- Çalışanları sürekli olarak eğitmek ve geliştirmek,

- İşgören tatminine odaklanan etkili bir ödüllendirme sistemi kurmak,

- Örgütsel amaç ve hedefleri açıkça tanımlamak ve çalışanlara iletmek, 
- Örgüt içinde genel sınırları belirleyerek bağımsız hareket etmeyi teşvik etmek,

- Koçluk, mentörlük ve danışmanlığı geliştirmek.

\section{Personel Güçlendirmede Karşılaşılan Sorunlar}

Personel güçlendirme örgütlerin verimlilikleri için son derece gerekli ve önemli bir kavramdır. Fakat uygulamada bazı sorunlar ile karşılaşılması da kaçınılmazdır. Bu sorunların ilk sıralarında yöneticilerin tutumları ve davranışları gelir. Yöneticiler kontrolör değil koç olmak durumundadırlar. Yönetsel sorunlar, güçlendirmenin önünde bir engeldir. Bu engeller kısaca şöyle sıralanabilir; yöneticilerin çalışanlar üzerindeki kontrollerini kaybedileceklerine dair korkuları, çalışanlarla yöneticilerin arasındaki ilişkilerde güç dengesinin değişmesi, orta kademedeki yönetim pozisyonlarının aradan çıkarılması ve yönetimin alışık bulunduğu itaatte büyük değişimler olacağı endişesidir. Personel güçlendirme uygulamalarında karşılaşabilecek diğer sorun unsurları içerisinde; yapılacak hataların ve eğitim-geliştirme maliyetlerinin yüksek olması, insanların değişimlere kapalı olması, verilen hizmetlerde standartların bozulma ihtimalinin olması sayılabilir (Odabaş, 2014).

Yöneticilerin ve işgörenlerin personel güçlendirmedeki yeni misyonları ve vizyonları şüpheyle karşılamaları ve tamamen yerine getirememeleri sık karşılaşılan bir durumdur. Güçlendirme süreçleri yöneticileri; komuta-kontrol odaklı yöneticilerden daha çok, liderlik görevini yerine getirerek rehberlik ederek ilerlemeyi sağlayan yöneticiler yapar. Bu görevi güç kaybı olarak algılayan yöneticiler açısından ne yazık ki güçlendirme sorun olmaktadır. Bu algı da "yöneticilerin yetki devri ve güçlendirmeden gizliden gizliye bir endişe ve korku duyduğu" düşüncesini desteklemektedir (Çetin ve Günay, 2001).

Personel güçlendirme konusunda yapılacak hataların maliyetlerinin yüksekliği, bireylerin değişime direnmeleri, örgüt kültürünün belli bir misyonu ve vizyonu pekiştirecek şekilde gelişmemesi başta gelen sorunlar olarak öne çıkmaktadır (Koçel, 2013). 


\section{Personel Güçlendirmenin İşletmeler Açısından Önemi}

İşletmelerde personel güçlendirmenin önemi pek çok açıdan önem arz etmektedir. Nitelikli personel kaliteli mal/hizmet, kaliteli mal/hizmet ise memnun müşteriler demektir. Müşterilerin memnun olması ise yüksek işletme imajından, yüksek müşteri bağlllığına, yüksek rekabet gücünden, yüksek karlılığa kadar birçok alanda etkili olacaktır.

İşletmelerde hem zihinsel hem de yapısal bir değişim sürecini ifade eden başarılı bir güçlendirme sürecinin ardından; işgörenlerin verimlilikleri artacak, astların kendilerini geliştirmeleri sağlanmış olacaktır. Ayrıca işletmeler; karar alma faaliyetlerini daha kısa sürede, hızlıca gerçekleştirerek, diş çevre koşullarına daha kolay uyum sağlayabileceklerdir. Böylesi personel güçlendirme faaliyetlerinin işletmelerdeki verimliliğin artmasına katkı sağlayacağı belirtilmektedir (Akçakaya, 2010).

Literatürde hizmet işletmelerinde güçlendirilmiş işgörenlerin, müşteri istek ve beklentilerini karşılama konusunda ve şikâyetlerinin çözümü konusunda daha faal bir rol oynadıklarının üzerinde durulmaktadır (Lashley, 1996). Corsun ve Enz (1999) yapmış oldukları çalışmada, güçlendirilmiş işgörenlerle müşterilerin ihtiyaçlarının karşılanış hızı ve tatmini arasında olumlu ilişkiler olduğunu tespit etmişlerdir (Corsun and Enz, 1999).

İşletmelerde personel güçlendirme, karar alma mekanizmasında, daha çok esnekliği, serbestliği ve yaratıcıllğ müşterilerin isteklerinin ve ihtiyaçlarının karşılanmasında ve şikayetlerinin çözümünde etkili olduğu için örgütsel bağlllık, iş tatmini ve verimliliği artırdığından kurumsal imajın artmasına da katkıda bulunmaktadır (Karakaş, 2014).

Personel güçlendirme müşterilere sunulan hizmetlerin kalitesinin iyileştirilmesi ve müşteri tatmininin sağlanmasında uygulanabilecek temel yöntemlerden biridir. Güçlendirilmiş işgörenler müşterilerin ihtiyaçlarını karşılamak üzere sahip oldukları akıllarını ve yeteneklerini kullanacaklar, onların problemlerini çözmek için ellerinden geleni yaparak hem müşterilerin tatmini artacak hem de işletmeleri kazanacaktır. Kendisine güvenilen ve güçlendirilen işgörenler müşterilere daha iyi hizmet sağlayan ve yaptıkları işten gurur duyan bireylerdir. Bununla beraber, işgö- 
renler de birer müşteridirler ve onların da yaptıkları işten tatmin olmaları gerekmektedir (Doğan ve Demiral, 2007).

Personel güçlendirme, işi yapanla karar vereni yakınlaştırdığından, işlerin yapılma süresinde tasarruf sağlamaktadır. İşgörenlerin özyeterlilik hislerini geliştirebilecek her türlü yönetim şekli personel güçlendirmesini sağlar. İşgörenler, işleriyle ilgili olarak kontrol ve sahiplenme duygusu hissettiklerinde personel güçlendirmesi gerçekleşmiş olur. Güçlendirilmiş çalışanlar, yaptıkları işlerin kendilerine ait olduğunu hisseder ve sonuçlarının da kendilerine ait olduğunu bildikleri için daha çok sorumluluk üstlenirler. İşlerin yürütülmesinde inisiyatif alır, işlerinden hoşlanır ve bunun sonucunda örgüt içindeki etkinlikleri artar (Çuhadar, 2005).

Personel güçlendirmenin işletmelere sağlayacağı faydaları aşağıdaki gibi sıralayabilmek mümkündür:

- Personel güçlendirme işletmelerin öğrenen bir organizasyon olmasına yardımcı olur. Zira güçlendirme ile personel daha fazla sorumluluk alacak, daha iyi öğrenmeye çalışacak ve bu şekilde öğrenen organizasyon olma yolunda adımlar atılacaktır (Doğan, 2003a).

- Personel güçlendirmeyle müşterilerin isteklerine hızlı cevap verilebilecek ve müşteri hizmetleri çok daha iyi hale gelerek mükemmelleşecektir. Müşteriler isteklerinin aksatılmadan kısa sürede karşılanmasını isterler (Frogoso, 2000). Örneğin bir müşteri şikayetini bildirmek üzere müşteri hizmetlerini aradığında hızlı ve çözüme ulaştıran yanıtlara ulaşmak ister. Ancak "patronum yok", "ilgiliye aktarıyorum" vb. yanitları duymak istemezler. Personel güçlendirme bu tür durumları azaltacağından daha memnun müşteriler ve daha bağlı müşteriler kazanilacaktır.

- Personel güçlendirmeyle sorumluluklar paylaşılacağından işletmelerde yöneticiler işletme adına daha önemli konulara yoğunlaşabileceklerdir.

- Personel güçlendirmeyle işgörenler inisiyatif kullanabileceklerinden işlerini yapmak için farklı seçenekler geliştirebilirler. İnisiyatiften yok olan işgörenler ise sürekli yakınırlar ve diğerlerinin harekete geçmesini bekler (Toktamışoğlu, 2001). 
- İşletmelerde performans güçlendirme karlılığı artıracaktır. Bu daha çok üretkenliğin artmasıyla genel giderlerin azalmasından kaynaklanir.

- Personel güçlendirmeyle işletme içerisindeki iletişim kanalları güçlü ve her yöne doğrudur. Bu durum da işletme içerisinde ortaya çıkabilecek sorunların çok daha hızlı bir şekilde çözümlenebilmesini sağlar.

- İşletmelerde personel güçlendirme sayesinde işgörenlerin sadakatleri ve bağlılıkları sağlanmış olur. Bu durum ise işgören devir hızını azaltır, işe devamsızlığı önler, işten ayrılmaların önüne geçeceğinden, işletmelerin yeni işgören bulma, eğitim, tazminat ödeme vs. masraflarını azaltacaktır.

Personel güçlendirmenin işletmeler için yukarıda sayılan önem ve faydalarının yanında Baltaş (2001) bu faydaları aşağıdaki gibi özetlemiştir (Baltaş, 2001);

- İş veriminde yükselme,

- İsgörenler sorumlulukları üstlendiği için, işlerin belli bir sürede ve daha kaliteli yapılması,

- İşgörenlerin daha fazla sorumluluk ve inisiyatif sahibi olması,

- Yaratıcı ve yenilikçi fikirlerin ortaya çıkması,

- Yüksek düzeyde ekip çalışması,

- İş tatmininin yükselmesi,

- Yöneticilere daha önemli konular üzerine yoğunlaşmalarına olanak sağlaması,

- Maliyetlerde tasarruf,

- Rekabet avantaji sağlaması.

\section{Sonuç ve Değerlendirme}

Günümüzün artan rekabet ortamında işletmelerin kendilerini her yönden güçlü hissetmeleri gerekmektedir. Sürdürülebilir rekabetin sağlanabilmesi için sadece üretim miktarlarının artırılması ya da yeni teknolojilerin takip edilmesi yeterli değildir. Elbette bunların yanında işletmelerin güçlü personellere sahip olması gerekir. Güçlü personel güçlü işletme demektir. 
Personel güçlendirme kavramı 1980'li yıllardan sonra işletme literatüründe sıkça kullanılan bir kavram haline gelmiştir. Personel güçlendirme ile işletmelerde görev yapan çalışanlara daha fazla sorumluluk, daha fazla yetki, özerklik, bilgi paylaşımı sağlandığından ortaya çıkabilecek sorunlara kısa sürede müdahale edilebilir. Bu ise üretimin artmasına, çalışanların memnuniyetlerinin, örgütsel bağlılık düzeylerinin yükselmesine ve daha pek çok açıdan fayda sağlayacağından işletmeler için son derece önemlidir.

Güçlendirilmiş personele sahip işletmelerde daha az işgören kaybı, daha az kaza riski, daha kaliteli üretim, daha memnun müşteriler, daha yüksek karlılık görülecektir. Personel güçlendirmede kimi zaman yöneticilerden kaynaklanan sorunlar da yaşanabilmektedir. Çünkü bazı yöneticilerin yetki paylaşımından dolayı kendi hakimiyetlerinin azalacağını, işgören karşısında söz haklarının kalmayacağını düşünebilmektedir.

Personel güçlendirme kısaca işletmelere yetki devri, katılımcı karar verme, iş zenginleştirme, performans değerleme, resmiyetin azaltılması vb. yoluyla rekabet avantajı sağlayabilecektir. Aynı şekilde güçlendirilmiş personel de daha cesur karar alabilme, sorumluluk üstlenebilme gibi davranışlarla işletmelere zaman kazandırabilecektir. 


\title{
EXTENDED ABSTRACT
}

\section{The Importance of Personnel Empowerment for Businesses}

\author{
Seçil Ulufer Kansoy \\ İstanbul Aydin University
}

During the industrialization period, production importance was much more valuable than workers for the companies that work production oriented. During those times, employees were just expected to do what was assigned and produce along with not having been given any right of self expression. Abondoning the production oriented understanding and giving authority an responsibility to their workers, the companies with modern management understanding gave importance to the approach of worker oriented production. In a business, the employees who perform a specific duty have the best skills and know the best knowledge about it based on the quality of the work done. At this point, the more the employees are empowered, the more powerful the business will be to that extent. The concept of personnel empowerment includes training and developing them utilizing from cooperation, team work and division of labor as well as the processes like expanding employees' the authority of decision-making.

Personnel empowerment doesn't consist of only a specific group work employees but all the employees that work in the businesses. In order to be successful in increasing competitive conditions with globalization, it is necessary to have a workforce equipped with various knowledge, skills and skills, highly motivated, adapting to its own objectives and business objectives. Peronnel empowerment plays an important role in improving performance in enterprises. Therefore, businesses should try to increase their position in global competition by taking their employees into development programs from time to time in areas of need. This will also increase the motivation of the personnel and increase their productivity. Personnel empowerment are practices and conditions that allow employees to do work that they find relevant and meaningful to their purposes, where their motivation, knowledge and abilities incre- 
ase, they want to act with their discretion, their belief that they can control events, and what they find meaningful and compatible with the purposes of the enterprise. In order to adopt the concept of personnel empowerment in a business, the presence of certain elements in the organizational culture is important. Factors such as employee responsibility, authority to participate in decisions, innovation, access to information and sharing of information, being able to act on common goals, reassuring employees, an open communication environment, training and development, teamwork, improvement and flexibility in working environments, appreciation of employees, development of competencies and abilities, and performance feedback are important for the formation and continuity of the culture.

The importance of personnel powerment in enterprises is important in many respects. Qualified personnel are quality goods/services, and quality goods/services mean satisfied customers. The satisfaction of the customers will be effective in many areas from high business image, high customer loyalty, high competitiveness, high profitability. After a successful powerment process that refers to both a mental and structural process of change in enterprises; the productivity of the employees will increase and the subordinates will be able to improve themselves. In addition, businesses; they will be able to adapt more easily to external environmental conditions by carrying out decision-making activities in a shorter time, quickly. Personnel empowerment is one of the basic methods that can be applied to improve the quality of services offered to customers and to ensure customer satisfaction. Empowered personnel will use their intellect and abilities to meet the needs of customers, and by doing their best to solve their problems, both customers' satisfaction will increase and their businesses will gain. With personnel empowerment, more responsibility, more authority, autonomy, information sharing can be provided to the employees working in the enterprises, so the problems that may arise can be intervened in a short time. This is extremely important for businesses as it will benefit from increased production, increased employee satisfaction, increased organizational loyalty levels and many other aspects. Businesses with empowered personnel will see less job loss, less accident risk, better quality production, more satisfied customers, higher profitability. There may also be problems 
with personnel powerment sometimes caused by managers. Because some managers may think that their dominance will decrease due to the sharing of power, they will not have a say in the face of the workforce.

In this study, the importance of personnel empowerment in terms of businesses is emphasized. Following the literature review and according to the qualitative research it is shown while personnel empowerment leads to decrease in production costs and turnovers, it leads to an increase in customer/client satisfaction, employee commitment and corporate image. With personnel empowerment, companies will gain a lot of advantages and more success. Companies that think like this will differentiate and come to the fore among themselves.

\section{Kaynakça / References}

Akçakaya, M. (2010). Örgütlerde uygulanan personel güçlendirme yöntemleri: Türk Kamu Yönetiminde personel güçlendirme, Karadeniz Araşttrmalart, 25, 145- 174.

Allanazarov, Y. (2008). Personel güçlendirme ve algllanan kontrolün örgütsel bağlllık üzerine etkisi: Kültürlerarası bir araştırma. Yayımlanmamış Yüksek Lisans Tezi. Erciyes Üniversitesi Sosyal Bilimler Enstitüsü, Kayseri.

Arslantaş, C. (2007). Dönüşümcü liderliğin psikolojik güçlendirme ve örgütsel vatandaşlık davranışı üzerindeki etkisi. Amme İdaresi Dergisi, 40(4), 81-101.

Baltaş, A. (2001). Değişimin içinden geleceğge doğru ekip çalışması ve liderlik. İstanbul: Remzi Kitabevi.

Bandura, A. (1989). Regulation of cognitive processes through perceived selfefficacy. Developmental Psychology, 25, 729-735.

Barutçugil, İ. (2004). Stratejik insan kaynakları yönetimi. İstanbul: Kariyer Yayınları.

Bingöl, D. (2014). İnsan kaynakları yönetimi. İstanbul: Beta Yayınevi.

Bolat, T. (2008). Dönüşümcü liderlik, personel güçlendirme ve örgütsel vatandaşlık davranışı ilişkisi. Ankara: Detay Yayıncılık.

Ceylan, A.; Çöl, G. ve Gül, H. (2005). İşin anlamlılığını belirleyen sosyalyapısal özelliklerin güçlendirmeye olan etkileri ve sonuçları üzerine bir araştırma. Doğuş Üniversitesi Dergisi, 6(1), 35-51. 
Corsun, D. and Enz, C. (1999). Predicting psychological empowerment among service workers: The effect of support-based relationships. Human Relations, 52(2), 205-224.

Çark, Ö. (2020). Dijital dönüşümün işgücü ve meslekler üzerindeki etkileri. International Journal Enterpreneurship and Management Inquries, 4(özel say11), 19-34.

Çark, Ö. (2021). Dijital üretim yönetimi. S. Özbey içinde, Dijital İşletme Yönetimi ve Yapay Zeka (s.91-115). Ankara: Detay Yayıncllı.

Çavuş, M. (2012). Personel güçlendirme: İmalat sanayii işletmelerinde bir araştırma. Journal of Yasar University, 3(10), 1287-1300.

Çetin, C. ve Günay, G. (2001). Yetki devri ve personel güçlendirmesi ilişkisi kamu ve özel sektörde bir uygulama, 9.Ulusal Yönetim ve Organizasyon Kongresi Bildiriler, İstanbul.

Çöl, G. (2004). Personel güçlendirme (Empowerment) kavramının benzer yönetim kavramları ile karşılaştırılması. Endüstri İlişkileri ve İnsan Kaynakları Dergisi, 6(2), 35-46.

Çuhadar, M. T. (2005). Türk Kamu Yönetiminde personel güçlendirme: Sorunlar ve çözüm önerileri. Erciyes Üniversitesi İktisadi ve İdari Bilimler Fakültesi Dergisi, 25, 1-21.

Doğan, S. (2003a). Personel güçlendirme-empowerment. İstanbul: Sistem Yayıncilik.

Doğan, S. (2003b). İşletmelerde personel güçlendirmenin önemi. İ.Ü. Siyasal Bilgiler Fakültesi Dergisi,29, 177-203.

Doğan, S. (2006). Büyük ölçekli işletmelerde insan kaynakları yöneticilerinin güçlendirilmiş bir iş çevresi yaratmaya ne kadar istekli ve hazır olduklarının tespitine ilişkin bir araştırma. Yönetim ve Ekonomi Dergisi, 13(2), 165-180.

Doğan, S. ve Demiral, Ö. (2007). İşletmelerde personel güçlendirme kültürünün yaratılmasıyla müşteri memnuniyetinin sağlanması. Selçuk Üniversitesi Karaman İ̈BF Dergisi, 9(12), 282-303.

Eren, E. (1998). Örgütsel davranış ve yönetim psikolojisi. İstanbul: Beta Yayınları.

Frogoso, H. (2000). An overview of employee empoerment: Do's and don'ts. http://www.iusb.edu/ journal/2000/fragoso.html adresinden alınd,, Erişim Tarihi: 3 Mart 2021 
Gümüştekin, G. ve Emet, C. (2007) Güçlendirme algılarındaki değişimin örgütsel kültür ve bağlllık üzerinde etkileşimi. Dumlupınar Üniversitesi, Sosyal Bilimler Dergisi, 17, 90-116.

Güven, M. (2001). Çağdaş bir yönetim yaklaşımı: personel güçlendirme. Marmara Üniversitesi Sosyal Bilimler Enstitüsü Dergisi, 4(16), 113-114.

Humborstad, S. and Perry, C. (2011). Employee empowerment, job satisfaction and organizational commitment an in-dept empirical investigation. Chinese Management Studies, 5(3), 325-344.

Karakaş, A. (2014). İşletmelerde personeli güçlü kılma yollarından personel güçlendirme. Dicle Üniversitesi Sosyal Bilimler Enstitüsü Dergisi, 6(11), 79-105.

Koçel, T. (2005). İşletme yöneticiliği. İstanbul: Arıkan Basım.

Koçel, T. (2013). İşletme yöneticiliği. İstanbul: Arıkan Basım

Lashley, C. (1996). Research issues for employee empowerment in hospitality organizations. International Journal of Hospitality Management, 15(4), 333-346.

Odabaş, İ. (2014). Yapısal güçlendirme ile örgütsel bağhllık arasındaki ilişkide psikolojik güçlendirmenin ara değişken rolü: Öğretmenler üzerinde bir uygulama. Yayımlanmamış Yüksek Lisans Tezi. İstanbul: İstanbul Kültür Üniversitesi, Sosyal Bilimler Enstitüsü.

Özçelik v.d. (2015). İnsan Kaynakları Yönetimi. İstanbul: Beta Yayınevi.

Özgen, H. ve Türk, M.(1997). Hizmet sektöründe rekabette başarının anahtar1: personel güçlendirme (Empowerment). Amme İdaresi Dergisi, 30(4),77.

Robbins, T., Crino, M. and Fredendal, L. (2002). An integrative model of the empowerment process. Human Resource Management Review, 12, 419443.

Russ, D. (1995). Empowerment: A matter of degree-executive commentary. Academy of Management Executive, 9(3), 29-30.

Schuler, R. (1995). Managing human resources. New York: West Publishing Company.

Spreitzer, G. (1995). Psychological empowerment in the workplace: Dimensions measurement and validation. Academy of Management Journal, 38(5), 1442-1465.

Tanyeli, H. (1970). Personel eğitimi. Ankara: BTí. 
Thomas, K., and Velthouse, B. (1990). Cognitive elements of empowerment: An interpretive model of intrinsic task motivatioan. Academy of Management Review, 15(4), 666.

Toktamışoğlu, M. (2001). Kot pantolonlu yönetici-iş yaşamında akıl ve ruhun sentezi. Ankara: MediaCat Kitapları.

Wilkinson, A. (1998). Empowerment: Theory And practice. Personnel Review, 27(1), 41.

\section{Kaynakça Bilgisi / Citation Information}

Ulufer Kansoy, S. (2021). Personel güçlendirmenin işletmeler açısından önemi. OPUS-Uluslararası Toplum Araştırmaları Dergisi, 18(Yönetim ve Organizasyon Özel Sayıs1), 1828-1848. DOI: 10.26466/opus.895900. 